\title{
A controvérsia jurídica sobre a tese do marco temporal e o conceito de renitente esbulho sob o olhar empírico: os Xavante e a TI Marãiwatsédé
}

\author{
Juliana Cristina da Rosa1 \\ Doutoranda Programa de Pós-Graduação em História \\ Universidade Federal de Mato Grosso \\ Paulo Sergio Delgado2 \\ Universidade Federal de Mato Grosso
}

\begin{abstract}
Resumo: Esse artigo tem como objetivo analisar a controvérsia jurídica sobre a tese do Marco Temporal e o conceito de renitente esbulho debatidos pelo STF a partir do julgamento de uma Ação Pública contra o reconhecimento em área contínua da TI Raposa Serra do Sol, conforme Portaria $n^{0}$ 534/05, do Ministério da Justiça, e que abriu brechas para uma série de interpretações e apresentação de uma proposta da CNA de Súmula Vinculante, bem como de parecer apresentado em 2017 pela AGU e aprovado pelo então presidente Michel Temer. A análise não será realizada através de debates hermenêuticos característicos de parte do campo jurídico, mas partindo de um caso empírico que demonstra a historicidade do processo de esbulho da terra reconhecida posteriormente como TI Marãiwatsédé. Neste contexto, a aplicação da tese do marco temporal e do esbulho renitente carece de perspectivas antropológicas e históricas capazes de evitar equívocos oriundos de interpretações jurídicas.

Palavras-chave: Marco Temporal; Esbulho renitente; Xavante; Marãiwatsédé.
\end{abstract}

\footnotetext{
${ }^{1}$ Cientista Social e Doutoranda em História pelo PPGHIS/UFMT.

2 Antropólogo e professor do Departamento de Antropologia e do PPGAS/UFMT.
} 


\title{
La controversia jurídica sobre la tesis del marco temporal y el concepto de renuente expropiación bajo la mirada empírica: los Xavante y la TI Marãiwatsédé
}

Resumen: Este artículo tiene como objetivo analizar la controversia jurídica sobre la tesis del Marco Temporal y el concepto de renuente expropiación debatidos por el STF desde del juicio de una Acción Pública contra el reconocimiento en área continua de la TI Raposa Serra do Sol, de acuerdo con la Ordenanza $n^{0}$ 534/05 del Ministerio de Justicia, que abrió brechas para una serie de interpretaciones y presentación de una propuesta de la CNA (Confederación de Agricultura y Ganadería de Brasil) de Súmula Vinculante, así como de dictamen presentado en 2017 por la AGU (Abogacía General de la Unión) y aprobado por el entonces presidente Michel Temer. El análisis no se realizará a través de debates hermenéuticos característicos del campo jurídico, sino partiendo de un caso empírico que demuestra la historicidad del proceso de expropiación de la tierra reconocida posteriormente como TI Marãiwatsédé. En este contexto, la aplicación de la tesis del marco temporal y de la expropiación renuente carece de perspectivas antropológicas e históricas capaces de evitar equívocos oriundos de interpretaciones jurídicas.

Palabras clave: Marco Temporal; Renuente Expropiación; Xavante; Marãiwatsédé.

\section{The legal controversy concerning the temporal demarcation thesis and the reluctant expropriation concept from the empirical perspective: the Xavante and the Marãiwatsédé Indigenous Land}

\begin{abstract}
This article aims to analyze the legal controversy about the temporal demarcation thesis and the reluctant expropriation concept, both debated by the STF (Supreme Federal Court). The controversy occurs since the judgment of a Public Action against the recognition in continuous area of the Raposa Serra do Sol Indigenous Land according to Ordinance n. 534/o5 of the Justice Ministry. The judgment opened opportunities for a variety of interpretations and generated a precedent. Therefore, CNA (Brazilian Confederation of Agriculture and Livestock) propounded a "Súmula Vinculante" as well AGU (Attorney-General of the Union) emitted a legal opinion submitted in 2017, approved by then President Michel Temer. Our analysis will not be performed through hermeneutic debates, which are characteristic of the juridical field, but starting from an empirical case that demonstrates the historicity in the expropriation process of the land, which later became known as Marãiwatsédé Indigenous Land. In this context, application of temporal demarcation thesis and of reluctant expropriation lacks anthropological and historical perspectives capable of avoiding misunderstandings resulting from legal interpretations.
\end{abstract}

Keywords: Temporal Demarcation; Reluctant Expropriation; Xavante; Marãiwatsédé. 


\title{
Introdução
}

No dia 20 de julho de 2017, foi publicado no Diário Oficial da União (DOU) o Parecer n. 001/2017 elaborado pelo consultor-geral substituto da Advocacia Geral da União (AGU), que foi acolhido pela advogada geral da União Grace Maria Fernandes Mendonça. O objetivo daquela publicação foi de tornar público a vinculação da administração pública federal às 19 salvaguardas institucionais às terras indígenas que forem demarcadas ou em processo de reconhecimento. Tais salvaguardas foram configuradas pelo Supremo Tribunal Federal (STF) como condicionantes fixadas no Acórdão da Petição (PET) 3.3884/Roraima (RR) referente ao julgamento envolvendo a demarcação da Terra Indígena (TI) Raposa Serra do Sol. No parecer o seu relator deixa conceituado o que são as salvaguardas institucionais às terras indígenas que:

\begin{abstract}
As difíceis e complexas questões jurídicas e sociais envolvidas no caso Raposa Serra do Sol exigiram do Supremo Tribunal Federal o desenvolvimento de processos de interpretação criativa da Constituição, especialmente de seus artigos 231 e 232, que perfazem o sistema de direitos e garantias fundamentais dos índios. Assim era de se esperar, tendo em vista o conturbado histórico de quase três décadas de infindáveis conflitos em torno da terra indígena, um complicado contexto social e político que tornou premente e necessária a construção interpretativa, a partir do texto constitucional, das dezenove salvaguardas institucionais às terras indígenas, no intuito de definir um quadro normativo constitucional que pudesse oferecer segurança jurídica aos processos de demarcação das terras e, assim, efetivar os direitos fundamentais dos índios.3.
\end{abstract}

Apesar da definição de que se trata de um quadro normativo, desde o ano de 2012 a AGU tenta efetivar como efeito vinculante 19 salvaguardas institucionais do caso Raposo Serra do Sol, pois publicou a Portaria n. 303 que previa a interpretação e aplicação daquelas salvaguardas. Contudo, no mesmo ano aquela portaria foi suspensa por outra Portaria, a de n. 308, e até 2016 não houve tentativas de aplicabilidade, pois os embargos contra a PET 3.388-4/RR impediam que os efeitos vinculantes pudessem ser de fato efetivados. No entanto, em 2017 o Parecer da AGU avalia que houve a intenção do STF em dar aplicabilidade geral às salvaguardas institucionais defendendo a "estrutura argumentativa" e a "eficácia e autoridade do STF", reiterando o "dever da Administração Pública de observar as decisões do STF"4.

Na oitava página do parecer da AGU se percebe uma sutileza leonina, pois o texto insere "a definição dessas condicionantes às demarcações de terras" referindo-se às 19 salvaguardas do processo da TI Raposa Serra do Sol, mas colocando no plural algo peculiar a um processo específico. Outro ponto do texto do referido parecer se destaca pela sua argumentação de cunho sofista que induz a uma interpretação equivocada do acórdão, ao sintetizar que seria "intenção da Corte de fixá-las [as salvaguardas] definitivamente como normas

${ }^{3}$ ADVOCACIA GERAL DA UNIÃO. Parecer n. 001/2017/GAB/CGU/AGU.

4 ADVOCACIA GERAL DA UNIÃO. Parecer n. 001/2017/GAB/CGU/AGU. 
definidoras de um regime jurídico para a demarcação de terras indígenas"5. Ressalta-se que a Corte não tem uma posição unânime sobre o tema e tampouco havia intenção de todos os ministros em considerar as 19 salvaguardas como conteúdo positivo com efeitos vinculantes para os demais processos de reconhecimento e demarcação de terras indígenas.

As 19 salvaguardas institucionais do caso Raposa Serra do Sol suscitaram uma série de controvérsias jurídicas sobre seu teor, sobretudo no que diz respeito à tese do marco temporal e o conceito de renitente esbulho. São esses os pontos escolhidos pela AGU como principais a serem adotados:

Como se vê, a Corte Suprema tem entendimento muito consolidado a respeito de dois tópicos fundamentais para a demarcação das terras indígenas: 1) a data da promulgação da Constituição, em 5 de outubro de 1988, como marco temporal de ocupação da terra pelos índios, para efeito de reconhecimento como terra indígena; 2) a vedação à ampliação de terras indígenas já demarcadas6.

O Parecer conclui que “[...] a Administração Pública Federal deve observar, respeitar e dar efetivo cumprimento à decisão do Supremo Tribunal Federal" referente às salvaguardas institucionais. No entanto, em 2009 a Procuradoria Geral da República (PGR) inicialmente questionou a validade dos efeitos vinculantes e o próprio relator do caso, o Ministro Roberto Barroso reconheceu que as 19 salvaguardas institucionais foram uma "decisão atípica" e afirmou que não é possível efetivar os efeitos vinculantes e:

\begin{abstract}
A decisão do STF sobre a demarcação da Raposa Serra do Sol não vincula juízes e tribunais quando do exame de outros processos relativos às terras indígenas diversas, explicou o ministro Barroso ao analisar outro ponto dos embargos da PGR. A decisão vale apenas para a reserva em questão. Nesse sentido, Barroso lembrou que a Corte já negou reclamações em outros casos, que alegavam desrespeito à decisão tomada nesta Petição.7
\end{abstract}

O ministro ainda lembrou que, do ponto de vista jurídico, não é possível retirar efeitos vinculantes de uma Ação Pública (PET 3.388-4/RR). Todas essas questões demonstram que não existe dentro do STF um único entendimento, existindo divergências de interpretação quanto à aplicabilidade das 19 salvaguardas institucionais às terras indígenas. Não apenas os efeitos vinculantes são motivos de debate e controvérsia jurídica, mas o próprio conteúdo das salvaguardas, sobretudo no que diz respeito ao marco temporal e ao renitente esbulho.

\title{
A controvérsia jurídica sobre a tese do Marco Temporal e o conceito de renitente esbulho
}

Em 19 de março de 2009 o STF estava julgando a PET 3.388-4/RR acerca de uma Ação Popular ajuizada pelo Senador Augusto Affonso Botelho Neto em

\footnotetext{
${ }^{5}$ ADVOCACIA GERAL DA UNIÃO. Parecer n. 001/2017/GAB/CGU/AGU, p. 17.

${ }^{6}$ ADVOCACIA GERAL DA UNIÃO. Parecer n. 001/2017/GAB/CGU/AGU.

7 SUPREMO TRIBUNAL FEDERAL. [Notícia] Plenário mantém condições fixadas no caso Raposa Serra do Sol. Quartafeira, 23 de $\quad$ outubro $\quad$ de $2013 . \quad$ Disponível $\quad$ em: 〈http://www.stf.jus.br/portal/cms/verNoticiaDetalhe.asp?idConteudo=251738> Acesso em: 23/o9/2017.
} 
face da União. A alegação era de que a União havia cometido uma série de equívocos durante o processo administrativo que fundamentava o pedido de delimitação da TI Raposa Serra do Sol. O STF manteve a demarcação em área contínua daquela TI, mas proferiu um Acórdão que fixou 19 salvaguardas institucionais à terra indígena Raposa do Sol. Parte de setores produtivos e instituições contrárias aos direitos dos povos indígenas construíram uma interpretação de que aquelas salvaguardas, que se referiam a um caso específico, se tornassem um conteúdo positivo a ser aplicado aos demais processos administrativos de reconhecimento e demarcação de TIs.

Na ocasião, o Ministro Carlos Ayres Britto foi relator do processo e seu voto-vista teve influência no texto final do Acórdão na medida em que a $11^{\mathrm{a}}$ salvaguarda continha a sua tese do marco temporal que foi inicialmente apresentada da seguinte forma8:

\begin{abstract}
Há de definir-se, ficando estreme de dúvidas, as terras realmente ocupadas expressão da Constituição - pelos indígena no já um tanto longínquo ano de 1988, marco temporal para assentar-se a insubsistência de títulos de propriedade e posses de terceiros, esclarecendo-se situações fáticas e jurídicas apanhadas pela carta federal.
\end{abstract}

No mesmo documento, o Ministro Carlos Ayres Britto retoma a Súmula do Supremo n. 650 que definiu: "Os incisos I e XI do artigo 20 da Constituição Federal não alcançam terras de aldeamentos extintos, ainda que ocupadas por indígenas em passado remoto". A partir disso, o ministro deixa claro o seu entendimento sobre o marco temporal:

I - o marco temporal da ocupação. Aqui é preciso ver que a nossa Lei Maior
trabalhou com data certa: a data da promulgação dela própria ( 5 de outubro de 1988)
como insubstituível referencial para o reconhecimento, aos índios, "dos direitos sobre
as terras que tradicionalmente ocupam”. Terras que tradicionalmente ocupam,
atente-se, e não aquelas que venham a ocupar. Tampouco as terras já ocupadas em
outras épocas, mas sem continuidade suficiente para alcançar o marco objetivo do dia
5 de outubro de 1988 . Marco objetivo que reflete o decidido propósito constitucional
de colocar uma pá de cal nas intermináveis discussões sobre qualquer outra
referência temporal de ocupação de área indígena. Mesmo que essa referência
estivesse grafada em Constituição anterior. É exprimir: a data de verificação do fato
em si da ocupação fundiária é o dia 5 de outubro de 1988, e nenhum outro." (Grifos
do texto)9.

O ministro citou em seu voto no julgamento do Mandado de Segurança n. 21.575-5 MS envolvendo a disputa entre fazendeiros e os Guarani. No seu entendimento, o fato dos indígenas estarem a mais de 27 anos longe dessas terras seria elemento impeditivo, uma vez que: "A atual Carta não assegura aos indígenas o retorno às terras que outrora ocuparam, seja qual for a situação jurídica atual e o tempo transcorrido desde que as deixaram10”.

Sua argumentação possui trechos interpretativos dramáticos sobre a possibilidade do retorno dos povos indígenas aos seus territórios como: "Imagine-se o que poderá vir a acontecer com áreas em que hoje existem 
grandes cidades e que outrora foram ocupadas por índios"11. E como exercício de retórica o ministro elaborou ainda os seguintes questionamentos:

Qual é o alcance do dispositivo no artigo 231 da Constituição federal de 1988? Implica a garantia de permanência dos indígenas nas suas terras? Assegura o retorno dos indígenas a terras em alguma época, ainda que perdida no tempo, ocupada, fulminando-se uma cadeia de títulos devidamente registrados?

Observa-se que o ministro Carlos Ayres Britto amarrou o direito dos povos indígenas garantido no artigo 231 da $\mathrm{CF} / 88$ à cadeia dominial de títulos de propriedades, e tão pouco se aventa ao histórico processo de violência, mortes e esbulho territorial daqueles povos. O ministro afirma ao final que: "Surge o problema alusivo ao interesse jurídico dos fazendeiros que possuem título de propriedade legitimado pelo Incra em área posteriormente demarcada.12” E a resolução do problema apresentado foi a citação de um voto do ministro Peçanha Martins no julgamento do Mandado de Segurança n. 4.821/DF cujo resultado foi a impugnação do pleito de demarcação da referida TI por ser "declarada de interesse social, para fins de reforma agrária”. Entretanto, o problema do interesse dos fazendeiros que possuem títulos não pode ser respondido com um caso de não demarcação por virtude de interesse social referente à assentamentos de reforma agrária do Incra.

Portanto, o problema das propriedades privadas devidamente tituladas precisa ser analisado considerando o histórico de aquisição dessas terras e não considerando, tão somente, casos de interesse social totalmente diversos da realidade dos casos analisados. No entanto, é legítima a preocupação do ministro para além da dimensão jurídica, pois:

Assentada de maneira definitiva a orientação do Supremo no caso em exame estando em jogo tema impregnado da maior importância jurídica, econômica e social, presente a determinação de imediata retirada de todos os cidadãos não-índios das terras demarcadasi3.

Essa preocupação aparece ainda mais claramente manifestada no voto do ministro Gilmar Mendes, e que foi analisada criticamente por José Afonso da Silva em seu Parecer sobre o marco temporal. Nele o advogado e professor da USP transcreveu a seguinte parte do voto do ministro:

Importante foi a reafirmação de marco do processo demarcatório, a começar pelo marco temporal de ocupação. O objetivo principal dessa delimitação foi procurar dar fim a disputas infindáveis sobre as terras indígenas, entre índios e fazendeiros, muitos das quais, como sabemos, bastante violentas. (SILVA, 2016:10).

Certamente uma nobre justificativa, mas que gerou mais um ponto criticado por José Afonso da Silva:

Fica claro, por esse texto, que o objetivo do marco estabelecido não é a proteção dos direitos dos índios, ainda que essa proteção seja uma exigência da Constituição. [...] Fica claro também que o objetivo enunciado é o de dar fim a disputas infindáveis sobre as terras não pelo cumprimento da regra constitucional que manda proteger e fazer respeitar todos os bens dos índios, ou seja, não pela coibição e repressão aos usurpadores, mas pela cassação dos direitos dos índios sobre elas. (SILVA, 2016:11).

11 STF. Petição 3.388. Rel. Min. Carlos Ayres Brito. Julgado em 24.09.2009, p. 115. 
Percebe-se, portanto, a controvérsia jurídica sobre a justificativa da tese do marco temporal. Mas não é apenas a justificativa que foi duramente criticada pelo jurista José Afonso da Silva: a própria definição da "data certa" de 5 de outubro de 1988 foi duramente criticada:

\begin{abstract}
"Marco temporal de ocupação das terras indígenas pelos índios" é um dos conceitos questionáveis estabelecidos pelo acórdão proferido no processo da Pet. 3.388 sobre as Terra Indígena Raposa da Serra do Sol, questionável em primeiro lugar porque fixado pretorianamente de modo arbitrário como sendo a data da promulgação da Constituição Federal de 5 de outubro de 1988. Questionável também por ter dado ao conceito uma dimensão normativa com aplicação geral a todos os casos de ocupação de terras indígenas. (SILVA, 2016:07).
\end{abstract}

Segundo o autor do Parecer, nenhuma palavra do artigo 231 da CF/88 “autoriza essa conclusão”. Outro jurista, Bruno Pegorari (2017), escreveu um artigo argumentando que a tese do marco temporal é uma "interpretação restritiva" do direito à terra dos povos indígenas, pois:

[...] A decisão apresenta um problema grave. Seu erro central foi restringir deliberadamente o direito originário a terra por meio de um marco temporal irrefletido que não guarda qualquer vínculo racional com a situação jurídica analisada, se não um mero simbolismo esvaziado e o discreto alívio de se pôr um ponto final no já tão prolongado debate. A verdade é que o estabelecimento arbitrário da referida data carrega o vício da anti-historicidade, ignorando o passado indigenista brasileiro e o caráter originário de seus direitos, assim como o histórico compartilhado das graves violações dos direitos humanos desses povos por parte de particulares e do próprio Estado. (PEGORARI, 2017: 249).

Essa argumentação do jurista parece adequada no tocante ao problema de ser uma tese, de fato, anti-histórica. Isso porque compreende a CF/88 como um marco de ruptura a partir da perspectiva do judiciário, sem considerar a historicidade das relações sociais, interétnicas e fundiárias que se configuraram ao longo do processo sóciohistórico que é peculiar e específico a cada caso de reconhecimento e demarcação das terras indígenas.

Outro elemento anti-histórico apontado por Osowski (2007. p. 336-337) diz respeito às recentes interpretações do STF quanto à posse "imemorial" dos povos indígenas:

Consoante já referido, não se trata de compreender ocupação tradicional como "posse
imemorial”, como quiseram parecer crer os Ministros do STF, pois evidente que os
conceitos não se confundem, tanto que essa discussão foi superada ainda quando da
elaboração atual Constituição. Tampouco, a ocupação tradicional pode ser restringida
pela "posse imemorial”. O termo, por si só, já remete à ideia de algo estático, sobre o
qual não se tem mais memória, o que certamente não se coaduna com o efetivo
exercício do direito à memória, história e a dinamicidade da cultura dos povos
tradicionais.

Essa característica de interpretação jurídica eminentemente anti-histórica de algumas questões envolvendo os direitos dos povos indígenas tem gerado críticas, como a presente no Parecer do jurista José Afonso da Silva, que se contrapõe marcadamente à tese do marco temporal ao historicizar o trecho do referido artigo 231 da CF/88: "São reconhecidos aos índios sua organização social, costumes, língua, crenças e tradições, e os direitos originários sobre as terras que tradicionalmente ocupam, competindo à União demarcá-las, proteger e fazer respeitar todos os bens”. Para o entendimento de José Afonso da Silva, se 
ACENO, Vol. 4, N. 8, p. 127-145. Ago. a Dez. de 2017. ISSN: 2358-5587.

Conflitos territoriais e socioambientais nas Amazônias (Dossiê).

houve em 1988 o reconhecimento dos direitos originários isso demonstra que tais direitos existiam anteriormente. Logo, para o autor:

[...] a Constituição de 1988 é o último elo do reconhecimento jurídico constitucional dessa continuidade histórica dos direitos originários dos índios sobre suas terras e, assim, não é o marco temporal desses direitos, como estabeleceu o acórdão da Pet. 3.388. [...] Pois bem, o documento que deu início e marcou o tratamento jurídico dos direitos dos índios sobre suas terras foi a Carta Regia de 30 de julho de 1611, [...] (SILVA, 2016:09).

Portanto, a CF/88 é um "reconhecimento constitucional" do direito originário das terras indígenas que foram sendo estabelecidas nas constituições anteriores, e não seria um ponto de ruptura no processo histórico de continuidade desse direito.

A perspectiva de uma continuidade histórica defendida no Parecer de José Afonso da Silva está na contramão do entendimento do ministro Carlos Ayres Britto, pois no seu voto no julgamento da Petição 3.388-4 ele até retoma os artigos das constituições anteriores citando o artigo 129 da CF de 1934: "Será respeitada a posse de terras de silvícolas que nelas se achem permanentemente localizando (sic), sendo-lhes, no entanto, vedado aliená-las”. Em seguida cita a CF de 1946 em seu artigo 216: "Será respeitada aos silvícolas a posse das terras onde se achem permanentemente localizados, com a condição de não a transferirem”.

É perceptível que o ministro tem conhecimento desses direitos anteriores à $\mathrm{CF} / 88$, mas que busca no ordenamento jurídico elementos para reforçar sua tese de que existe a necessidade de uma ocupação dos povos indígenas no momento em que essa CF foi efetivada. Conforme já salientado, um dos principais questionamentos deixa de ser apresentado, qual seja, o porquê de uma população indígena que reivindica constitucionalmente o reconhecimento do que restou de seu território não o estar ocupando em 5 de outubro de 1988. Se historicamente as constituições anteriores a de 1988 respeitam "aos silvícolas" a posse de suas terras, constata-se que o Estado foi omisso quanto a este respeito, e promoveu a partir dos anos de 1950 uma série de projetos de governo que levaram ao esbulho de territórios indígenas.

No entanto, em nenhum momento o ministro cita artigos das mesmas constituições que versavam sobre o direito dos povos indígenas atrelados à proibição de esbulho das terras indígenas anteriores à 1988. Já no Acórdão referente ao julgamento da PET 3.388/RR houve o reconhecimento de que em muitos casos não havia a possibilidade do povo indígena estar ocupando a área pleiteada como TI por motivo de esbulho das terras em questão. No entanto, o texto gerou novas controvérsias:

\footnotetext{
A tradicionalidade da posse nativa, no entanto, não se perde onde, ao tempo da promulgação da Lei Maior de 1988, a reocupação apenas não ocorreu por efeito de renitente esbulho por parte de não-índios. Caso das "fazendas" situadas na Terra Indígena Raposa Serra do Sol, cuja ocupação não arrefeceu nos índios sua capacidade de resistência e de afirmação da sua peculiar presença em todo o complexo geográfico da "Raposa Serra do Sol" (Grifo nosso) 14.
} 
A controvérsia gira em torno da compreensão do STF em relação ao conceito de renitente esbulho, pois em decisão tomada no julgamento do Agravo no Recurso Extraordinário 803462/MS ficou formulado:

\begin{abstract}
Renitente esbulho não pode ser confundido com ocupação passada ou com desocupação forçada ocorrida no passado. Há de haver, para configuração de esbulho, situação de efetivo conflito possessório que, mesmo iniciado no passado, ainda persista até o marco demarcatório temporal atual (vale dizer, na data da promulgação da Constituição de 1988), conflito que se materializa por circunstâncias de fato ou pelo menos, por uma controvérsia possessória judicializada.
\end{abstract}

Essa compreensão foi duramente criticada por José Afonso da Silva, pois na sua compreensão os direitos dos povos indígenas não podem ser considerados como posse do direito civil, o que o jurista considerou uma "torção semântica calamitosa”, pois:

\footnotetext{
De fato, o esbulho é um instituto do direito possessório civil, considerado o ato pelo quão o "possuidor" é provado da posse que lhe é arrebatada pelo esbulhador. Oras, as terras dos índios são congenitamente possuídas, e sua relação com elas é de direito constitucional, pelo instituto do indigenato, e não do direito civil. (SILVA, 2016:12).
}

Ademais, considerou ser a interpretação que mais destoa dos direitos dos povos indígenas pois o conceito de "renitente esbulho" em vez de "esbulho renitente" acaba por "[...] irrogar os ônus sobre a renitência, com o que impõe aos índios esbulhados a obrigação de provar os fatos”, conforme Silva (2016:12). Esse seria um equívoco por parte justamente do STF que é a instância responsável pelo direito das minorias e guardião da Constituição Federal, e para Silva (2016, p. 16): “Ora, as regras da Constituição sobre os direitos indígenas têm a natureza de direito protetivo de minorias e, portanto, devem ser compreendidas na conformidade do contexto de vivência dessa minoria”. Logo, para o jurista, se o STF permanecer nesse entendimento, seriam os povos indígenas os responsáveis em comprovar o esbulho de suas terras e não os fazendeiros e demais proprietários os encarregados em demonstrar a legalidade de títulos sobrepostos a TI.

No entanto, não é somente o problema do ônus da prova, pois sendo sociedades ágrafas, a maior parte dos povos indígenas não tinha acesso à legislação do país que titulou suas terras como sesmarias durante a colonização e depois de 1850 como propriedades privadas devidamente registradas em cartório, mesmo se tratando de TI. Ademais, a lógica da propriedade privada não faz parte do universo dos povos indígenas e que mantêm outras formas de relação com a terra e seus limites quando se trata de relações com outros povos indígenas.

Diante das transformações históricas da legislação fundiária, algumas cadeias dominiais de propriedades privadas podem remontar ao início do século passado, pois foi o período em que aqueles que detinham a posse de uma área, poderiam registrá-la como propriedade privada. Esse processo de transformação das terras em propriedade privada se intensificou a partir de 1891, pois foi no início do período republicano que os estados da federação passaram a legislar e a vender terras consideradas "devolutas", mesmo tendo conhecimento da presença de povos indígenas nas áreas comercializadas. 


\begin{abstract}
Bem se sabe que esse movimento de outorga de terras públicas no centro-oeste se deveu ao malsinado art. 64 da Constituição de 1891, dispositivo que gerou alguma controvérsia e até consequências não autorizadas, ao declarar pertencer aos Estados as terras devolutas situadas nos seus respectivos territórios. Diante desse dispositivo, alguns Estados começaram a estabelecer disposições sobre legitimação de posse, reconhecimento de domínio, discriminações das terras indígenas como se fossem devolutas. Com certeza não havia boa-fé nesses procedimentos, porque terras ocupadas pelos índios certamente não eram, nunca foram, nem são devolutas. (SILVA, 2016:14).
\end{abstract}

Logo, é recorrente que fazendeiros e demais proprietários apresentem títulos registrados de terras que foram comercializadas pelos estados, como o caso dos produtores de arroz de Roraima em litígio com a TI Raposa Serra do Sol e os produtores se soja e cana-de-açúcar do Mato Grosso do Sul que têm títulos que remontam ao início do século passado. No entanto, nesses títulos não está registrado a presença de povos indígenas que foram sendo expulsos ao longo desse processo de transformação da terra da União em propriedade privada através da comercialização de terras pelos estados ou mesmo pela prática de grilagem e a expropriação das terras de forma violenta. Ademais, constata-se que a não presença de povos indígenas nos títulos decorre de um apagamento seletivo para justificar o título de propriedade.

Justamente nesse sentido que surge a outra crítica do jurista José Afonso da Silva que diz respeito à configuração de esbulho proposta no julgamento do Agravo no Recurso Extraordinário 803462/MS. Nela há a exigência de um "conflito que se materializa por circunstâncias de fato ou pelo menos, por uma controvérsia possessória judicializada", no entanto para Silva (2016:16):

\begin{abstract}
Os julgados do Supremo fundados nessa concepção reconhecem os conflitos entre índios e não-índios, mas nunca reconhecem a sua fonte, que é a invasão, a grilagem ou a usurpação das terras dos índios. Mas, às vezes, se sente nas entrelinhas que os julgadores entendem que os índios é que provocam o conflito. O esbulho é praticado pelos nãoíndios, de sorte que os ônus do conflito e sua solução deveriam recair nesses esbulhadores e não sobre os índios. Quando exige deles que, mesmo iniciado no passado, sua resistência persista até o marco demarcatório temporal atual (vale dizer, na data da promulgação da Constituição de 1988), conflito que se materializa por circunstâncias de fato ou, pelo menos, por uma controvérsia possessória judicializada. Vale dizer, requer-se dos índios um comportamento típicos dos nãoíndios no que tange à luta pelos seus direitos, não se levando em conta que os direitos dos índios não são dos indivíduos como tal mas da comunidade e que os índio s e as comunidades indígenas são sujeitos ao regime tutelar de competência da União (Lei 6.001, de 1973, art. $7^{\circ}$ ).
\end{abstract}

Ao que parece o fato incontestável é o de que a tese do marco temporal e do renitente esbulho provocaram uma série de controvérsias, o que Bruno Pegorari (2017), descreveu como um "ambiente jurídico de fragilidade", pois na sua interpretação:

[...] o tratamento dados aos direitos humanos dos povos indígenas pelo judiciário brasileiro, com destaque ao direito à terra, vem se deteriorando progressivamente, culminando, hoje, no momento jurídico de maior fragilidade do curto período do novo constitucionalismo brasileiro (CF/1988) (PEGORARI, 2017: 244). 
Um dos principais problemas apresentados pelo autor têm relação com o objetivo principal do STF que é de defender a CF/88, sobretudo as cláusulas pétreas que trazem as garantias da dignidade da pessoa humana e os direitos humanos de minorias. Isso porque dentro de uma democracia representativa com um presidencialismo de coalisão, é comum observar que grupos de interesse se consolidam como a maioria no Congresso Nacional, como no caso brasileiro, e tem poder de deliberar em causa própria e em detrimento dessas minorias. O exemplo disso é a "bancada ruralista" que se consolidou com um dos mais significativos grupos de interesse atuando no Congresso Nacional e que têm desenvolvido estratégias para promover mudanças no processo de demarcação de terras indígenas como a Proposta de Emenda à Constituição (PEC) 215 e a Proposta de Súmula Vinculante apresentada pela Confederação Nacional da Agricultura e Pecuária do Brasil (CNA) 2012.

Portanto, é possível identificar que essas controvérsias jurídicas dão margem à uma série de ações de grupos de interesse que atuam de forma a utilizar politicamente alguns argumentos debatidos na esfera do poder judiciário para alcançar seus objetivos políticos em casos concretos. Logo, apenas a argumentação que fomente o debate jurídico não é suficiente para embasar a tese do marco temporal e o conceito de esbulho renitente. É preciso que olhares históricos e antropológicos possam contribuir para compreender a especificidade histórica de cada processo de demarcação de terra indígena, pois é necessário que casos de esbulhos e remoções de povos indígenas sejam narrados por esses povos que têm na memória do grupo esse histórico. Para Osowski (2017, p.337):

\begin{abstract}
Hoje, o que se pretende é lembrar, testemunhar, tornar pública a verdade dos povos indígenas em relação às remoções forçadas de suas terras e as violações atreladas a esse contexto, trazendo para o espaço público a memorialidade dessa posse, a partir da compreensão da realidade fática e não da institucionalmente construída. [...] Assim, a lembrança das violências, dos deslocamentos forçados e da usurpação de terras por parte dos brancos continua na esfera do memorável por parte dos povos indígenas. Essa memória frequentemente está associada a lugares de memória, ou seja, a espaços territoriais onde essas memórias foram sendo construídas.
\end{abstract}

Segundo Ricouer (2007) e Pollak (1989), as memórias são construídas socialmente, sendo seletivas, impregnadas de esquecimentos e silenciamentos, e, portanto, devem ser consideradas como fontes que não necessariamente conduzirão à uma "verdade" absoluta, mas trazem à tona memórias que ficaram à margem da história oficial. $\mathrm{O}$ caso de esbulho de terras e violência contra os povos indígenas, com omissão por parte do Estado, não foi inserida de forma abrangente na história oficial e, em muitos casos, é negada.

No mesmo sentido podemos dizer que a memória pública oficial, produzida pelas autoridades públicas legítimas, negou trechos inteiros da história coletiva em benefício, na maior parte dos casos, de outras lembranças que tornaram a realidade mais apaziguadora ou mais aceitável. Nos casos de traumas ligados às guerras intestinas devastadoras, com sacrifício ou destruição de populações, o mecanismo de negação serve, em parte inconscientemente, para cicatrizar provisoriamente as feridas coletivas (MICHEL, 2010: 17). 
Logo, superar a negação dessas memórias e narrativas dos povos indígenas são fundamentais não apenas para a elaboração dos laudos antropológicos - que são peças do processo jurídico de reconhecimento e demarcação de suas terras tradicionalmente ocupadas - mas por possibilitarem ao jurista analisar e interpretar o processo histórico que envolve o esbulho em questão.

Para melhor compreender a importância da historicidade do processo de esbulho, este artigo analisa, sob o olhar antropológico e histórico, um caso empírico da luta dos Xavante pelo reconhecimento e demarcação da TI Marãiwatsédé que enfrentaram desde a década de 1950. Esse objetivo está diretamente ligado à concepção de Bensa (1998) de que existe uma relação entre os acontecimentos e processos históricos, tal qual o esbulho das terras Xavante e a luta pela terra que atravessou décadas.

\section{O marco temporal no caso da TI Marãiwatsédé}

Em 1993 a Portaria 363 do Ministério da Justiça reconheceu Marãiwatsédé como terra tradicionalmente ocupada pelos Xavante e em 1998 através de Decreto Presidencial foi homologada. Nessa situação a TI Marãiwatsédé foi registrada em cartório como propriedade da União em conformidade com os direitos assegurados pela $\mathrm{CF} / 88$, seguindo o processo administrativo definido pelo Decreto 1.775/96 e Estatuto do Índio (6.001/73). Durante todo esse processo os Xavante não puderam ocupar a área demarcada como TI Marãiwatsédé, pois foram removidos dali desde 1966 e somente, por meio de decisão judicial, tiveram condições de retornar em 2003. Todavia, não puderam novamente entrar na TI pois foram impedidos por posseiros e grileiros que haviam invadido a área remanescente da Agropecuária Suiá Missú (implantada em território Xavante - Marãiwatsédé). Esta invasão ocorreu logo após a promessa do presidente da Agip Petrolli, Gabrieli Cagliari, em 10 de junho de 1992, por ocasião da Eco92 em devolver a área da Agropecuária Suiá Missú aos Xavante. Diante disso, em 2003 acamparam nas margens da Rodovia MT 158 e, posteriormente, por decisão liminar da justiça, se instalaram provisoriamente numa pequena área de seu território. Somente em 2012, com a desintrusão dos não-índios, que os Xavante puderam de fato, exercer o domínio sobre toda a TI Marãiwatsédé.

Logo, os Xavante de Marãiwatsédé não ocupavam suas terras no ano de 1988 quando a CF/88 reconheceu os direitos dos povos indígenas aos seus territórios tradicionalmente ocupados. E esse fato foi o suficiente para que a tese no marco temporal fosse acionada pelos não-índios num processo jurídico que afirmava não serem eles (os Xavante) ocupantes da área demarcada e homologada. E de fato, o juiz federal Pedro Francisco da Silva do Tribunal Regional Federal (TRF) em seu julgamento assim considerou: 
pelos dirigentes da Agropecuária Suiá-Missú, na década de sessenta. Talvez não houvesse índios naquelas terras no ano de 1988, mas decerto que ainda havia a memória de seus antepassados, traduzida no "sentido anímico e psíquico de continuidade etnográfica", no dizer do Min. Carlos Britto, no julgamento do caso que ficou conhecido como "Raposa Serra do Sol” [PET n. 3.388/RR]15.

Portanto, o juiz federal considerou parte da própria argumentação do Ministro Carlos Ayres Britto para seu julgamento, considerando que mesmo sem ocupar de fato a área em 1988, os Xavante de Marãiwatsédé mantinham uma ocupação entendida em "sentido anímico e psíquico de continuidade etnográfica”. De outro modo, pode se dizer que mantinham ligação ctônica, ou seja, de forma mais profunda e em sentido para além do material, mas uma relação que perpassa a memória dos antepassados que lá viveram e se perpetua entre os vivos da geração presente. Mas para se compreender a não aplicabilidade do marco temporal no caso do reconhecimento, demarcação e homologação da TI Marãiwatsédé é preciso historicizar um processo histórico marcado pelo renitente esbulho dessas terras.

\title{
O Renitente Esbulho dos Xavante de Marãiwatsédé: a remoção de 1966 e a invasão de 1992
}

\begin{abstract}
Em 2010, o juiz federal problematizou a não ocupação dos Xavante em Marãiwatsédé em 1988 e também relatou o esbulho das terras dos indígenas em sua decisão: 22. O Laudo Pericial Antropológico, fartamente instruído por documentos históricos, corrobora as assertivas contidas no Parecer da FUNAI, não deixando margem a nenhuma dúvida de que a comunidade indígena Xavante Marãiwatsédé foi despojada da posse de suas terras na década de sessenta, a partir do momento em que o Estado de Mato Grosso passou a emitir título de propriedade a não-índios, impulsionados pelo espírito expansionista de "colonização" daquela região brasileira.

23. As provas dos autos revelam, escandalosamente, as condutas espúrias praticadas pelos dirigentes da Agropecuária Suiá-Missú, no ano de 1966, quando promoveram uma verdadeira expulsão dos indígenas de suas terras. Primeiro submetendo-os a extrema necessidade de sobrevivência, em função da acentuada degradação ambiental, que resultou na drástica redução dos meios de subsistência e posterior alocação dos mesmos em uma pequena área alagadiça onde ficaram expostos a inúmeras doenças.

24. Em seguida, dissimulando os atos de violência num suposto espírito humanitário, articularam a transferência da comunidade indígena Xavante Marãiwatsédé para a Missão Salesiana de São Marcos para, alguns anos depois, requerem junto à FUNAI uma certidão atestando a inexistência de aldeamento indígena nas referidas terras, a fim de respaldar a obtenção de financiamento junto à SUDAM16.
\end{abstract}

Portanto, o juiz levou em consideração as provas documentais presentes no Relatório de Identificação da Área Indígena "Marãiwatsédé” que havia sido coordenado pela antropóloga Patrícia Mendonça de Rodrigues em 1992. Nesse documento são encontradas evidências da primeira situação de esbulho com uma série de entrevistas com lideranças e com antigos trabalhadores da Suiá Missú que relataram o contato e a remoção dos indígenas em avião da Força Aérea Nacional (FAB), além de documentos do Serviço de Proteção ao Indio (SPI) que registraram a localização das aldeias de Marãiwatsédé e a necessidade

15 TRIBUNAL REGIONAL FEDERAL DA PRIMEIRA REGIÃO. Apelação Civil n. 2007.01.00.051031-1/MT de 25/08/2010, p.05.

16 TRIBUNAL REGIONAL FEDERAL DA PRIMEIRA REGIÃO. Apelação Civil n. 2007.01.00.051031-1/MT de 25/08/2010, p.04. 
do Estado agir para evitar o esbulho de terras indígenas por parte de estrangeiros e demais compradores ou grileiros de terra. Um desses ofícios foi em parte transcrito por Rodrigues (1992: 24):

[...] Seguindo o exemplo do estrangeiro, mais duas famílias procedentes do Araguaia, deslocaram-se para a Barreira da Bacaba, nas proximidades da aldeia de Marú-Acéde, onde estão instaladas no afã de construírem fazendas. [...] Os locais escolhidos pelos invasores para a instalação de fazendas ficam situados nos arredores da aldeia acima citada, onde se encontra radicado um grupo arredio de índios Xavante.

Esse e outros ofícios foram redigidos por Ismael Leitão do SPI solicitando a adoção de "medidas enérgicas e urgentes" em relação ao esbulho das terras dos Xavante. Mas nada foi feito por parte do governo federal e no final da década de 1950, o estado de Mato Grosso vendeu uma significativa parte do território de Marãiwatsédé pelo valor de Cr\$20.000.00o,oo (vinte milhões de Cruzeiros), diretamente a Ariosto da Riva e outras que adquiriu outras partes de terceiros, acumulando uma área total de 695.843.8551 hectares17 que deram origem à Agropecuária Suiá Missú, conforme identificado no Laudo de Perícia Judicial da Reserva Indígena Marãiwatsédé (2003) ao analisar a Certidão Vintenária18.

Após o contato em 1959, no momento da abertura da mata e instalação da sede da Fazenda Agropecuária Suiá Missú os Xavante trabalharam para Ariosto da Riva em troca de presentes e comida, e depois foram deslocados para uma área alagadiça sem condições de sobrevivência até que os empresários procuraram a Missão Salesiana de São Marcos e “[...] persuadiram os seus superiores a aceitarem nela os Xavante da Suiá” (OLIVEIRA, 1990, p.72).

\footnotetext{
Isso acontecia em 1966. Os Xavantes foram transportados em avião da FAB, em número de 263, tendo morrido boa parte deles aos poucos dias depois de chegados a São Marcos, vitimados por uma epidemia de sarampo. Essa porém não é a versão publicada na imprensa, conforme se pode ver na reportagem publicada por $\mathrm{O}$ ESTADO DE SÃO PAULO - em 25/04/69. (CASALDALIGA, 1971, p. 21).
}

Nesse primeiro esbulho ocorreram mortes de lideranças, dentre elas, o cacique Caetano, vitimados pelo sarampo, conforme narrado pelo seu filho o cacique Damião Paridzané:

Depois que chegou em São Marcos, como ele [Tibúrcio] estava contando, não teve
nem um ano para aparecer doença que aconteceu. Depois que chegou aqui, com dois
dias o pessoal já estava de sampo. Quando chegou em São Marcos. [...] Morreu
muito... morreu, morreu bastante. Adultos, velhos. [...]
Cento e sessenta. O padre Pedro falou 'cento e pouco'; Mestre Mario [outro padre]
falou em Cuiabá também que foi cento e cinquenta. [...] Cento e cinquenta
morreram... o padre me falou cento e sessenta. Meu pai, logo que chegou, pegou a
doença e ficou sofrendo dois dias [...]. Ai começou de morrer muitos. Meu pai morreu
dois dias depois. Daí começou: noite toda, dia todo... carregaram [os mortos] de
carroceria de trator levando no cemitério para enterrar. Noite toda, dia todo. Foram
morrendo todas. No mesmo dia, nem passou quinze dias [...] morre, mas junta: trator
encosta e padre manda "encosta lá, lá está morrendo já.. Ai gente botando em cima da

17 Código Cadastral do Imóvel: 901.083.003.611-1 e 901.083.002.820-o. In: Moreira Leão (2003) e conforme Registro Tórrens, Livro número 01 de 05/12/1971.

18 Certidão Vintenária registrada no $1^{\circ}$ Serviço Notarial e Registros da Comarca de Barra do Garça, Estado de Mato Grosso sob número 7.585, livro 3-L de 10 de janeiro de 1963. 
carroceria e levando onde que tem cemitério [...]. Está tudo enterrado lá em São Marcos. [...] Escapou pouca gente19 (Relato Oral Damião Paridzané, 1992).20

Independente da exatidão do número de mortos, essa situação é chocante e a antropóloga Inês Bueno Rosa definiu no Laudo Antropológico Terra Indígena Marãiwatsédé (2006) a transferência de Marãiwatsédé para São Marcos como um "ato genocida". Mesmo na época, essa epidemia foi noticiada no Jornal Diário da Noite em 14 de setembro de 1966 com o subtítulo "A morte faz recepção" no qual narra que: "Os 236 novos habitantes de São Marcos, procediam da fazenda Suiamissú [Sic!]”. Apesar da notoriedade da tragédia que recaiu sobre os Xavante, nenhuma ação foi feita por parte do Estado.

No entanto, os próprios Xavante sobreviventes empreenderam ações com o objetivo de retornar à Marãiwatsédé, sendo que o antigo gerente da Fazenda Suiá Missú, Dário Carneiro, relatou uma dessas ações:

\begin{abstract}
Ai os sobreviventes, eles não quiseram mais ficar na missão. Eu não estava sabendo disso porque eu estava a seiscentos quilômetros de distância e não estava sabendo. Pensei que já tinham se readaptado e os padres tivessem resolvido o problema. Ai passados alguns meses, eu tô lá na fazenda quando surgem meia dúzia de índios. Eu lembro até hoje quem eram, quais são, muitos deles estão vivos ainda, bem velhinho, mas vivos. Esses índios chegaram a pé, mal podiam andar porque andaram muito, né. $\mathrm{Ai}$ eu fui num lugar separado com eles e ficamos conversando e eles falaram pra mim que queriam voltar. Voltar pra Suiá. Eles e todo o resto, o restante da tribo, da aldeia. Ai eu falei 'agora sim que vai ser, né'. Ai eu chamei o gerente e falei 'olha os índios querem voltar', aí ele falou pelo rádio e ai foi decidido que eles não podiam voltar prá fazenda porque já tinham saído de livre e espontânea vontade com autorização de Serviço de Proteção ao Índio, né, e não podiam retornar pra fazenda, não tinha mais espaço (Relato Oral Dário Carneiro, 2010. Grifos nossos)21.
\end{abstract}

A luta pelo retorno à Marãiwatsédé começou logo após a remoção para a Missão Salesiana de São Marcos. Além da busca junto à fazenda Suiá Missú, os Xavante também buscaram apoio para o seu retorno junto à autoridades:

Essa deportação foi presenciada por outros Xavantes da região e quando o Sr. Ministro do Interior Cel. Costa Cavalcanti, em abril de 1969 visitou aldeias dos Xavantes, estes lhe pediam que providenciasse a devolução da terra [...]. (CASALDALIGA, 1971, p. 21-22. Grifos nossos).

Três décadas depois um artigo denominado Viagem à "Suiá Missú" (1991) escrito pela antropóloga Iara Ferraz descreveu que 306 Xavante remanescentes de Marãiwatsédé viviam na Aldeia Água Branca e reivindicam aquela porção de seu território e o retorno para lá, além de uma "indenização por perdas e danos por terem sido banidos de suas terras" (FERRAZ, 1991, p. 7208-7211). Naquele ano a Agropecuária Suiá Missú pertencia ao grupo italiano ENI/Agip Petrolli S.A. e era administrada pela filial Agip do Brasil Ltda, que passou a ser fortemente criticada pelo fato de ser uma estatal italiana com negócios sobre um território indígena. Por uma série de pressões internacionais, sobretudo da Campagna Nord/Sud (CNS), e um movimento de luta dos Xavante e aliados,

19 A quantidade considerável de pausas e rupturas na narração se deve ao fato de que o discurso indígena tem como característica a repetição de frases ou ideias para dar ênfase. Para dar maior fluidez à narrativa se optou por cortes que não alteram o conteúdo narrado. 
ocorreu o pronunciamento do presidente da empresa italiana durante a Rio 92 prometendo a devolução da área aos índios.

Em 1992 então foi realizado a delimitação da área remanescente da Suiá Missú identificada como terra indígena através do laudo antropológico. No entanto, não foi possível o retorno dos Xavante, pois a área foi invadida por posseiros e grileiros incentivados por políticos locais, que organizaram uma reunião dentro da área da Suiá Missú, o Posto da Mata, que foi transmitida regionalmente por meio da Rádio Mundial FM. Durante essa reunião a área remanescente da Suiá foi dividida e alguns discursos de políticos e advogados aludiam que o povo Xavante não era produtivo e traria o atraso pra região, além de ser apontado abertamente sobre a "ojeriza" que a população local tinha em relação aos Xavante (Rosa 2015). Após essa reunião houve uma invasão sistemática da área e se iniciou a batalha jurídica:

\begin{abstract}
O ano de 1992 marca não somente o início da invasão de Marãiwatsédé, mas também a luta de ambas as partes nos tribunais. Tanto a Fundação Nacional do Índio (FUNAI), em nome dos índios, quanto os invasores, representados por seus advogados, entraram na Justiça para tentar resolver o impasse: a primeira, solicitando a desintrusão da terra indígena. Os segundos com o intuito de anular o trâmite demarcatório legítimo da TI. Os dois processos correram em paralelo e, em todas as instâncias, a Justiça brasileira reconheceu o direito dos Xavante à posse de seu território. (OPAN/ANSA, 2013, p.8).
\end{abstract}

As batalhas jurídicas continuaram a ser travadas nas duas décadas seguintes. A demarcação e homologação da TI Marãiwatsédé já haviam ocorrido e em 2000 foi determinado e autorizado o retorno dos |Xavante, mesmo com os posseiros ocupando as terras. Segundo o cacique Damião Paridzané essa foi uma oportunidade:

\footnotetext{
Aí percebi e vi enxerguei no futuro falei para nosso pessoal se continuar desse jeito se a gente seguir ocupando a reserva de Pimentel, nunca vai melhorar, comecei de pensar, olha eu vou passar na FUNAI, conversar com presidente da FUNAI, Claudio Romero, disse pra ele: Nós queremos voltar para Marãiwatsédé, mas eu quero que a FUNAI batalhar, lutar, junto ao governo federal para poder retomar a terra de Marãiwatsédé, a terra de Marãiwatsédé é nossa origem (Relato Oral Damião Paridzané, 2012, grifos da entrevistadora22)
}

Em 2002 os Xavante retornaram em direção à Marãiwatsédé, mas com o bloqueio dos posseiros, acabaram por acampar por meses na margem da Rodovia 158, quando perderam três crianças para desnutrição e contaminação da água de um córrego. Novamente o povo Xavante passava por uma situação de penúria em meio à luta pelo retorno à Marãiwatsédé. Depois adentraram a área demarcada ficando em apenas uma fazenda aguardando até 2012 quando ocorreu a desintrusão dos não-índios da TI, conforme Rosa (2015).

\title{
Considerações Finais
}

Através da luta dos Xavante pelo retorno à Marãiwatsédé é possível identificar alguns pontos de incongruência em relação à tese do marco temporal 
e do esbulho renitente. Conforme já apontado, em 1988 os Xavante não estavam em Marãiwatsédé pois haviam sofrido o primeiro esbulho ao serem removidos para a Missão Salesiana São Marcos. Após décadas se deslocando dentro das terras de outros Xavante e depois de terem fundado a Aldeia Água Branca, não tinham conseguido apoio e notoriedade suficiente para a sua luta pelo retorno à Marãiwatsédé.

O que seria juridicamente colocado como renitente esbulho pode ser configurado desde 1966 quando buscaram apoio para poder voltar, mas não tiveram êxito. Somente em 1992 é que torna-se manifesta e oficializada sua luta pelo retorno e mesmo diante disso, sofreram um novo processo de esbulho, quando os posseiros e grileiros invadiram a área remanescente da Suiá Missú após ser prometida a devolução à eles. A judicialização dessa luta pelo retorno à Marãiwatsédé é um exemplo do renitente esbulho com ação judicializada, mas se for considerar a tese do Marco Temporal, essa judicialização ocorreu depois de 1988.

Portanto, se a tese do Marco Temporal e a concepção de renitente esbulho forem considerados sem levar em consideração as especificidades e a historicidade de cada caso, haverá risco de deslegitimar juridicamente o direito à terra dos povos indígenas que não tem uma história de luta pela terra tão linear e pontual quanto imaginada pelo Ministro Ayres Britto. O caso de Marãiwatsédé mostra que quando pensada historicamente e antropologicamente a tese do marco temporal não se sustenta. Semelhante ao Xavante de Marãiwatsédé, outros povos indígenas foram compulsoriamente expulsos de seus territórios, seja pela ação ou inércia do Estado, seja pela ação de grileiros de terras que lançaram mão de todo tipo de violência e intimidação, e não estavam fisicamente presentes em seus territórios em 05 de outubro de 1988. Todavia, eles mantem laços com seus locais de origem que extrapolam a temporalidade que tentam lhes impor.

\section{Bibliografia}

BENSA, Alban. Da microhistória à uma antropologia crítica. In: REVEL, Jacques (Org.). Jogos de Escala - a experiência da microanálise. Rio de Janeiro: Editora Fundação Getúlio Vargas, 1998.

MICHEL, Johann. Podemos falar de uma política de esquecimento? Revista Memória em Rede. Pelotas, v.2, n.3, ago.-nov. p. 14-26. 2010.

OLIVEIRA, Ariovaldo Umbelino. Amazônia: monopólio, expropriação e conflitos. Campinas: Papirus. 1990.

OSOWSKI, Raquel. O Marco Temporal para demarcação de Terras Indígenas, memória e esquecimento. In: Revista Mediações, v.22, n. 2, jul./dez. 2017, p. $320-246$. 
PEGORARI, Bruno. A tese do "macro temporal da ocupação" como interpretação restritiva do direito à terra dos povos indígenas no Brasil: um olhar sob a perspectiva da Corte Interamericana de Direitos Humanos. In: $A R A C \hat{E}$ - Direitos Humanos em Revista. Ano 4, n. 5, fev.2017, p. 242-262.

POLLAK, Michael. Memória, esquecimento, silêncio. In: Revista Estudos Históricos, Brasil, v. 2, n. 3, p. 3-15, 1989.

Memória e identidade social. In: Estudos Históricos, Rio de

Janeiro, v. 5, n. 10, p. 200-212, 1992.

RICOEUR, Paul. A memória, a história, o esquecimento. Campinas-SP: Editora UNICAMP, 2007, (p.423-459).

ROSA, Juliana Cristina da. A Luta pela Terra Marãiwatsédé: Povo Xavante, Agropecuária Suiá Missú, Posseiros e Grileiros do Posto da Mata em disputa (1960-2012). 2015. Dissertação de Mestrado, História, UFMT, 2015.

\section{Fontes Documentais}

ADVOCACIA GERAL DA UNIÃO. Parecer n. oo1/2017/GAB/CGU/AGU.

CASALDÁligA, P. [Carta] Uma Igreja da Amazônia em conflito com o latifúndio e a marginalização social. 1971. Disponível em: http://servicioskoinonia.org/Casaldaliga/cartas/1971CartaPastoral.pdf. Acesso em: 08/o8/2014.

DELUCI, Luciana A.S. \& PORTELA, Cristiane de Assis. Marãiwatsédé: Memória de Luta, Resistência e Conquista. In: XXVII Simpósio Nacional de História: ANPUH, 2013.

FERRAZ, Iara. Viagem à Suiá Missú, 1991. Disponível em: http://www.noticiasagricolas.com.br/dbarquivos/iara-ferraz-laudofunai.pdf\%CB\%83. Acesso em: 06/04/2014.

FERRAZ \& MAMPIERI. [Artigo]. Suiá Missú: um mito refeito. In: ISA Instituto Socioambiental, Povo Indígenas no Brasil 1991/95, 1994.

MOREIRA LEÃO, J. [Laudo]. Laudo de Perícia Judicial da Reserva Indígena Marãiwatsédé (2003).

OPAN, ANSA. Marãiwatsédé: Terra da Esperança. 2012. Disponível em: http://amazonianativa.org.br/Biblioteca.html. Acesso em: 05/11/2013.

RODRIGUES, Patrícia de Mendonça. [Laudo]. Relatório de identificação da área indígena "Marãiwatsédé". Brasília: FUNAI, Portaria n. 9 de 20/01/1992.

ROSA BUENO, Inês. [Laudo]. Laudo Antropológico Terra Indígena Marãiwatsédé. Ação Civil Pública número 950000679- MPF (2006).

SILVA, José Afonso da. [Parecer] Parecer sobre a situação do direito indígena à terra. 2016, p. 2-25. 
SUPREMO TRIBUNAL FEDERAL. Petição 3.388. Rel. Min. Carlos Ayres Brito. Julgado em 24.09.2009, p. 1-121.

Acórdão Petição 3.388. Julgado em 24.09.2009. pp. 71-85. p.77.

Súmula n. 650. Julgada em 24.09.2003.

SUPREMO TRIBUNAL FEDERAL. [Notícia] Plenário mantém condições fixadas no caso Raposa Serra do Sol. Quarta-feira, 23 de outubro de 2013. Disponível em: 〈http://www.stf.jus.br/portal/cms/verNoticiaDetalhe.asp?idConteudo=251738〉 . Acesso em: 23/09/2017.

TRIBUNAL REGIONAL FEDERAL DA PRIMEIRA REGIÃO. Apelação Civil $n$. 2007.01.00.051031-1/MT de 25/08/2010.

VALE DOS ESQUECIDOS. Documentário-longa Metragem. Direção: Maria Raduan. Fotografia: Sylvestre Campe, color, (72 min.): Tucura Filmes, Brasil, 2010. Disponível em: http://valedosesquecidos.com.br/\#ficha-tecnica/mariaraduan Acesso em: 25/04/2012. 